\title{
Język przedstawiony, czyli świat współczesnej prozy
}

\author{
The presented language or the world of modern prose
}

\author{
Bogumiła Kaniewska \\ Wydział Filologii Polskiej i Klasycznej, Uniwersytet im. Adama Mickiewicza w Poznaniu, \\ ul. Fredry 10, 61-701 Poznań, Polska; \\ e-mail: kanbo@amu.edu.pl
}

\begin{abstract}
The article is dealing with the place taken by language reflection in modern literary theory. Poststructural breakthrough in the Humanities had become a period of opening up to new inspiration, and most of all to "language learning". Much more important than the direct impact of the deconstruction was a change of consciousness: hereby the structuralist paradigm as the dominant way of talking about literature became exhausted. One academic discourse was replaced by the multitude of languages, and the multiplicity of rhetoric. The certainty of interpretation was replaced by interpretative doubts. That distrust embraced everything: not only the methodology, but the literature itself. A literary work ceased to be an objective structure, and its meaning a function of order. In this situation of discipline language, as art material, becomes the object of special attention of authors and researchers. The significance of language experiments is present in modern Polish prose, especially in prose by Wiesław Myśliwski.
\end{abstract}

Keywords: literature material; cultural theory; articulation of experience; modern Polish prose.

Od dłuższego czasu reprezentowaną przeze mnie (i ulubioną) dyscyplinę, jaką jest teoria literatury, dręczą pytania o charakterze podstawowym i - rzekłabym - ontologicznym (by nie powiedzieć: autotematycznym): pytania o to, czy istniejemy. Dzieje myśli humanistycznej zatoczyły koło: na przełomie XIX i XX wieku myślenie o historii zainspirowało antypozytywistyczny przełom, wyodrębniając nauki o kulturze z ogółu nauk, dookreślając ich procedury i narzędzia badawcze, definiując przedmiot. To z przełomu antypozytywistycznego zrodziła się nowoczesna historia, teoria i historia literatury, językoznawstwo, etnologia itd., itd., zdolne do autodefinicji i określenia własnych procedur badawczych. Po stu latach kierunek przemian okazuje się odwrotny - inne dyscypliny „pożyczają” od literatury jej sposób artykułowania przekonań o rzeczywistości, a granice między dziedzinami ludzkiej myśli stają się przepuszczalne. Ów nowy stan humanistyki przenikliwie opisuje Ryszard Nycz: 
Tendencja do kwestionowania istnienia odrębnych, zewnętrznych przedmiotów badania jako hipostaz pozbawionych empirycznego osadzenia pojawia się w większości nauk humanistycznych i społecznych [...]. Jeśli zaś idzie o literaturoznawstwo, to nie tylko literackość już dawno przestała być uznawana za właściwy przedmiot nauki o literaturze (jak chciał Jakobson), ale też przestało nim być pojęcie literatury jako dziedziny estetyczno-językowej fikcji [...] (2006: 35).

Tenże badacz, opisując nową sytuację teorii literatury, umiejscawia ją w obrębie tzw. „słabego profesjonalizmu”, czyli profesjonalizmu, którego charakter jest „ograniczony i zrelatywizowany do historycznego uniwersum kultury” (Nycz 2006: 35). Wśród różnych aspektów literaturoznawstwa podlegających krytycznej weryfikacji a momentami nawet bezwzględnej anihilacji jeden pozostaje zawsze aktualny - choć różnie formułowany i definiowany - a mianowicie świadomość językowej natury dzieła literackiego oraz - co za tym idzie - konieczność uwzględnienia refleksji nad językiem. Wydaje się wręcz, że jeśli w czymkolwiek czujemy się - jako teoretycy literatury - jeszcze profesjonalistami, to przede wszystkim zawdzięczamy owo profesjonalne poczucie świadomości tworzywa. Inaczej mówiąc: im mniej wiemy, czym jest (i czym nie jest) przedmiot naszych badań zwany literackością, tym mocniej staramy się uchwycić językowego charakteru humanistyki.

Kiedy zatem Grzegorz Godlewski dokonuje próby nowego zdefiniowania literatury, w perspektywie antropologicznej, pisze:

Najbardziej obiecujący wariant związku literatury i antropologii, w moim przekonaniu, powstaje na gruncie, który pozwala partnerom zachować autonomię, a łączącą ich relację oprzeć na tym, co dla każdego z nich swoiste. Gdy zatem literatura występuje jako szczególna praktyka językowa człowieka, jako sztuka słowa, $[. .$.$] antropologia podejmuje zadanie rozpoznania tak$ ujmowanej literatury jako zjawiska kulturowego (2008: 274).

Trudno wyobrazić sobie, by badania owej ,praktyki językowej” mogły obyć się bez językoznawczej empirii - tym bardziej że i definicje literatury nowoczesnej wyraźnie ogniskują się wokół pojęcia języka. Jak pisze Michał Paweł Markowski: w literaturze nowoczesnej

język nie jest wtórny wobec rzeczywistości (nie przedstawia jej), ale ją współtworzy. Z tego powodu język nie naśladuje rzeczywistości, ale odsłania jej problematyczny - a nawet potworny, nieoswajalny - status. Tym samym wynajdywanie (inwencja) języka jest odnawianiem oblicza świata (2007: 54).

Podobny punkt widzenia pojawia się wcześniej w myśleniu Ryszarda Nycza, który, pisząc o modernistycznej epifanii, określa literaturę jako miejsce ,gdzie świat wkracza dopiero w przestrzeń doświadczenia i zarysowuje na horyzoncie ludzkiego poznania" i nazywa

tym szczególnym momentem ludzkiego doświadczenia, w którym procesowi nastawania „,bezimiennej” realności zachodzą drogę znaki, akty kategoryzacji i nadawania sensu. Tam i wtedy właśnie ślad staje się tropem, literatura „zaszyfrowanym zapisem” rzeczywistości (2001: 12). 
Kulturowe, poststrukturalistyczne myślenie o literaturze zbliża się zatem do refleksji nad językiem - i to pojmowanym nie jako kontekst, ale jako jedyna rzeczywistość - nie tyle dana literackiemu światu, co realnie się w nim objawiająca, stanowiąca nie tylko wyraz, ale i rację bytu, nie tylko formę, ale i treść dzieła literackiego.

Paradoksalnie stanowisko takie zajmowali także dekonstrukcjoniści, dokonujący - zdaniem Anny Burzyńskiej - w swej antyteorii rozprawy z tradycją Kantowską, „która przede wszystkim traktuje prawdę jako rodzaj wertykalnego stosunku między przedstawieniami, a tym, co jest przedstawiane - język zaś jako system przedstawień (czyli rozłączność: istnieje coś poza językiem, co język ukazuje)" (2013: 417) ${ }^{1}$. Efektem tego sposobu myślenia była specyficzna metoda pracy z tekstem, którą Ryszard Nycz ujmuje w trzech zasadniczych tezach:

1. nie ma tekstu literackiego samego w sobie - metoda ta sprzeciwia się zatem idei „literackości” opartej na przekonaniu o istnieniu esencjalnych właściwości decydujących o przynależności tekstu do literatury; dzieło literackie „okazuje się nadzwyczaj złożonym, aktywnie współdziałającym z instytucjonalnymi porządkami i wrażliwym na zmiany historycznej semantyki, kulturowym konstruktem";

2. nie ma nic poza tekstem: zakwestionowanie realistycznej reprezentacjiświat, który przedstawia dzieło jest iluzją, nie obrazem, wytwarzaną przez retoryczne mechanizmy języka oraz konwencje;

3. każde odczytanie jest niedoczytaniem (por. Nycz 2000: 9-10).

Atakując, przedrzeźniając, wyszydzając klasyczną szkołę interpretacji zmierzającą ku odkryciu sensu, dekonstrukcjoniści zatrzymywali się na poziomie de Saussure'owskiego signifiant - nie wykraczając poza bardzo precyzyjne, choć dysseminacyjne analizy językowe. Dekonstrukcjonistyczna, antyhermeneutyczna rozbiórka tekstu posługuje się przede wszystkim wiedzą językoznawczą, badając etymologię i słowotwórcze konstrukcje poszczególnych wyrazów.

Rozproszenie sensów, odsłonięcie niezborności tekstu wynikało z przekonania, że dzieło literackie wyczerpuje się i spełnia w swoim kształcie językowym. O dziwo, dekonstrukcja nie odchodzi w tym założeniu daleko od strukturalizmu, który - choć stosował diametralnie różny styl lektury - również postrzegał tekst jako twór autonomiczny. Przypomnijmy, że, według Janusza Sławińskiego, doktrynalne minimum strukturalizmu

sprowadza się do koncepcji dzieła jako wysoce zorganizowanego tworu słownego - wypowiedzi (ewentualnie tekstu). Twór taki stanowi rezultat podwójnej operacji: wyboru i kombinacji znaków czerpanych z dwóch systemów - językowego i literackiego (tradycji). Wytyczają one obszar potencjalności dzieła - rezerwuar jego możliwości. Elementy dzieła odsyłają nie tylko do siebie nawzajem i do całości, którą współtworzą, ale równocześnie do odpowiednich klas elementów, stanowiących jego systemowe tło (2001: 16).

${ }^{1}$ Fragmenty wyróżnione kursywą, cytowane przez autorkę, pochodzą z: Rorty 1996: 86. 
Bez względu na to zatem, w którą stronę i w jakim celu zmierzał literaturoznawczy przełom współczesności, zawsze mieścił się on w obrębie myślenia o języku i zawsze wymagał od swych przedstawicieli powrotu do "twardego" językoznawczego profesjonalizmu.

Dlaczego tak się dzieje? To, oczywiście, tylko hipoteza - otóż dzieje się tak ze względu na właściwości (dążenia, zamierzenia, cele) samej literatury. Jestem mocno przywiązana do - mało zapewne odkrywczej - tezy, iż przemiany w literaturoznawstwie są konsekwencją zmian w literaturze. Ta koncentracja na języku samym - poza jego funkcją przedstawieniową - jest, moim zdaniem, ściśle związana $\mathrm{z}$ przemianami, jakim podlegała w wieku XX kategoria mimesis. Jak słusznie zauważa Erich Auerbach (1968), mimesis jest kategorią historycznie zmienną, mimo swego uniwersalizmu wymusza bowiem na kolejnych epokach konieczność redefiniowania, określania na nowo swego znaczenia. Wiek XX dokonał w tym względzie charakterystycznego przesunięcia, zauważonego choćby przez Bachtina czy teoretyków aktów mowy. Kwestionując możliwość przełożenia rzeczywistości na język - co znajduje swoje odzwierciedlenie choćby w Ingardenowskiej koncepcji dzieła literackiego - nie zakwestionowano jednak samej zdolności literatury do naśladowania. Problemem pozostawało pytanie, co właściwie naśladuje literatura? Najprostsza odpowiedź brzmiałaby następująco: naśladuje nie tyle rzeczywistość, ile sposoby mówienia o rzeczywistości, metody artykułowania doświadczenia czy komunikowania się.

Zdaniem Georga Steinera, na przełomie XIX i XX wieku, między rokiem 1870 a 1930, ma miejsce kulturowy i filozoficzny przełom; pisze dalej Steiner: „załamanie przymierza między słowem a światem stanowi jedną z niewielu rewolucji ducha w historii Zachodu i określa naszą współczesność" (1994: 47).

„Winę”, powiada Steiner, za zerwanie kontraktu ponosi literatura przełomu wieków, odkrywająca, że za pomocą języka nie zbliżamy się do żadnej rzeczywistości poza językiem samym. Założenia te doprowadziły - powtórzmy za autorem Zerwanego kontraktu - do pustki, aksjologicznej nicości, nihilizmu. Autor Zerwanego kontraktu, choć niechętny opisywanym przez siebie przemianom, dostrzega, że świadomość kryzysu wywołuje potrzebę pogłębionej refleksji nad językiem. Ta ostatnia prowadzi do zerwania z jednoznaczną koncepcją słowa (znamię kryzysu) na rzecz wielu, równoległych koncepcji czy filozofii języka. Ujmijmy to w następujący sposób: po „zerwaniu kontraktu” z rzeczywistością, język zawiera „kontrakty” szczegółowe, pojedyncze, zdeterminowane przez kontekst, w jakim jest ujmowany. Zamiast definicji języka mamy dziś do czynienia $\mathrm{z}$ całym szeregiem aspektów, przez które natura języka jest ujmowana i opisywana. Jak już wspominałam, strukturaliści koncentrowali się na autoteliczności słowa, sensach ukrytych w wewnętrznej logice języka i kształcie skonstruowanego w nim komunikatu - język traktowali jak tworzywo, autonomiczną strukturę rządzoną wewnętrzną dynamiką lub jako narzędzie komunikacji uwikłane w złożony, nadawczo-odbiorczy schemat. Kognitywiści wolą dostrzegać w języku modele ludzkiej 
percepcji. Bachtin widział słowo uwikłane w złożone relacje z innymi słowami. Derrida - w kontekstach doraźnych, momentalnych, w dysseminacyjnym gąszczu rozchodzących się znaczeń. Lacan postrzega język jako prawo domagające się interioryzacji, Foucault - jako mechanizm ustanawiania władzy nad społeczeństwem i jednostką. Przykłady można mnożyć - każdy z nich, rozpatrywany w izolacji, rości sobie prawo do kompletności, uniwersalności, wyczerpania problemu. Zestawione obok, oświetlają się wzajemnie i ujawniają swój ,,aspektowy sposób bycia" - semiotyczny, kulturowy, hermeneutyczny, psychologiczny, pragmatyczny, ekspresywny etc.

Kres logocentryzmu służy zatem refleksji metajęzykowej na różnych poziomach. Dialektyka końca działa i w tym wypadku: kres logocentryzmu oznacza początek nowego sposobu istnienia języka, nowych sposobów jego badania. Jak pisał Andrzej Mencwel:

W kulturze nie tylko wartości bowiem, ale i środki komunikacji dodają się do siebie, choć zasady tego dodawania nie są arytmetyczne, lecz swoiste i muszą być każdorazowo indywidualnie ujmowane. [...] w kulturze XX wieku współistnieją elementy kultury oralnej, kultury pisma, kultury druku i kultury audiowizualnej czy też elektronicznej (2006: 63).

Toteż słowo w literaturze trzeba na nowo definiować, uwzględniając zmienny kontekst historyczny i estetyczny - status języka w utworze literackim przypomina status gatunków literackich, każdorazowo wytyczających przestrzeń hermeneutyczną (Balbus 2007: 165) czy konstytuujących się każdorazowo w konkretnym utworze (Balcerzan 2007: 135).

Słusznie postulował Nycz, by spojrzeć na literaturę jak na „formę artykulacji doświadczenia" (Nycz 2006: 41), trudno jednak nie zauważyć, iż owo doświadczenie dotyczy w literaturze także samego doświadczenia języka, jego funkcji i ograniczeń. W zmieniającym się repertuarze motywów i problemów doświadczenie językowe jest tym, co nie zmienia się nigdy, choć przybiera rozmaite kształty. Każdy pisarz, każdy poeta staje przed pytaniem: jak wyrazić i każdy tekst zawiera w sobie implicite odpowiedź na to pytanie. Nawet jeśli pragnie wyrazić wyłącznie brak zaufania do języka jak Mallarmé.

Takich postaw zauważyć można w najnowszej literaturze bardzo wiele, by wymienić choćby Obsoletki Justyny Bargielskiej badającej język przedstawiania śmierci czy twórczość Magdaleny Tulli ukazującą kreacyjne aspekty języka w przedstawianiu historii, traumy. W ten sposób piszą Wojciech Kuczok, Dorota Masłowska, Michał Witkowski, Ignacy Karpowicz, tworząc rodzaj literatury „słychanej", wysłuchującej rozmaite rejestry języka, tworzącej ze sposobu mówienia rodzaj ideologii, postrzegania świata. Podobnie rozumie swe literackie posłannictwo Jerzy Pilch, rysując świadomość rodzoną poprzez konwencje kulturowe, za pomocą których myślimy o świecie, czy Wiesław Myśliwski - dokonujący w swojej twórczości filozoficznej refleksji nad językiem. Na tym ostatnim przypadku chciałabym się skupić nieco dokładniej. 
Pisarz bardzo wyraźnie wskazuje nie tylko na korzenie swej prozy, ale także i na funkcję, jaką odgrywa w niej język, którego, jak deklaruje, uczył się od polskich chłopów. Mówi tak: „W człowieku niczym w tyglu wytapiają się słowa, zdania, opowieści, w tyglu jego doświadczeń, cierpień i radości. Tylko ten własny język człowieka jest w stanie go opowiedzieć” (Myśliwski 2007: 205).

Myśliwski, trwając przy koncepcji języka pierwszego, a więc słowa, które wyposażone jest w zdolność nazywania (a zatem i powoływania do istnienia) kontestuje (o ile to dobre słowo) abstrakcyjną naturę języka. Lęk przed ,słowami na wolności" wyraża explicite narrator Traktatu:

Są przecież takie słowa, które nie mają swoich stałych znaczeń. Słowa wymienne na wszystkie nasze pragnienia, marzenia, tęsknoty, myśli. Można by powiedzieć, słowa bezcielesne, zabłąkane we wszechświecie innych słów, słowa, które szukają swoich znaczeń czy, lepiej, byłoby powiedzieć, swoich wyobrażeń. [...] Takich słów trzeba się jednak strzec [...] (Myśliwski 2006: $63)$.

Ów ścisły związek słowa z mówiącym, słowa z kontekstem jest cechą charakterystyczną dla kultury oralnej, opierającej się - jak pisze Andrzej Mencwel - na jednym sposobie komunikacji: „Tym sposobem komunikacji jest mowa żywa, z całym jej psychodynamicznym czy też werbomotorycznym kontekstem" (2006: 79). Słowo odnosi się zawsze do konkretnej sytuacji, nie funkcjonuje w przestrzeni abstrakcyjnej, nigdy nie jest abstrakcyjnym „znakiem” (Ong 1992: 109), lecz raczej konkretem stopionym $\mathrm{w}$ jedno $\mathrm{z}$ tym, co oznacza. Kultura oralna jest, na co zwraca Grzegorz Godlewski, kulturą funkcjonalną czy inaczej - definiowaną przez funkcję, pragmatykę. „Działanie sztuki oralnej polega również na tym, że sprawia ona coś poza samą sobą, choć przez to właśnie, że sama się staje. Pełni więc funkcję wehikułu: świat, do którego odsyła, jest przez nią przywoływany" (Godlewski 2008: 61).

A może bardziej stanowczo: konstytuuje świat, uobecnia go w słowach, stwarza? Nietrudno zauważyć, że wszyscy bohaterzy Myśliwskiego mówią, opowiadają, relacjonują, każda z narracji wypływa z potrzeby ujęcia własnego życia w ramy opowieści. Wyraźnie zarysowana sytuacja „mówienia” (czyli stylizacja na monolog wypowiedziany) przywołana jest ostentacyjnie tylko w Traktacie o łuskaniu fasoli, w pozostałych powieściach mamy do czynienia z przywoływaniem wypowiedzi osadzonej w ramach konkretnej, osobowej relacji. We wszystkich przypadkach jest to relacja nacechowana głęboką asymetrią: słuchacz, adresat monologu milczy, jego obecność jest implikowana kształtem relacji, pojawianiem się funkcji fatycznej, zwrotach do odbiorcy (który albo nie przejawia chęci kontaktu, albo jest odbiorcą zakwestionowanym: chorym, wyimaginowanym, w najlepszym razie - wątpliwym). Jest to nieprzypadkowe, mówienie jest dla wszystkich tych narratorów stwarzaniem świata, stwarzaniem siebie, konstruowaniem własnej tożsamości. Kiedy człowiek przestaje mówić, kiedy traci zdolność do opowieści o sobie, przestaje być - motyw milczenia jest najbardziej tragicz- 
nym motywem w świecie Myśliwskiego. Prymarna, magiczna rola słowa styka się w ten sposób z nowoczesnym pojmowaniem tożsamości. Jak pisze Katarzyna Rosner:

Tożsamość własna jednostki to poczucie refleksyjnie rozumianej (biograficznej, autonarracyjnej) ciągłości. Może być ona w pewnym stopniu komunikowana innym, zależy jednak nie od zachowań i interakcji z innymi, lecz od zdolności utrzymywania ciągłej autonarracji. Tożsamość, jak i konstytuująca ją autonarracja, nie jest w żadnym momencie życia jednostki ustalona, gotowa (2003: 42).

Powiada Anthony Giddens, że „refleksyjność «ja» jest ciągła i wszechogarniająca" (2010: 108), a opowieść o sobie zawsze uwzględnia dotychczasowy przebieg życia, co pozwala antycypować dalszy jego przebieg (w terminologii badacza - trajektorię). Giddens pisze:

\begin{abstract}
'Ja' tworzy trajektorię rozwoju od przeszłości do antycypowanej przyszłości. Jednostka przystosowuje swą przeszłość analizując ją ze względu na to, czego spodziewa się po (refleksyjnej i zorganizowanej) przyszłości. Trajektoria tożsamości jest spójna i wynika z poznawczej świadomości różnych faz przebiegu życia. To właśnie przebieg życia, a nie wydarzenia w świecie zewnętrznym, staje się dominującą „,figurą tła” w sensie gestalt. Nie jest całkiem tak, że wszystkie wydarzenia zewnętrzne czy instytucje to „nieokreśloność”, na tle której wyraźnie wyróżnia się jedynie przebieg życia (2010: 108).
\end{abstract}

Monologi narracyjne bohaterów Myśliwskiego zdają się literacką ilustracją procesu, o jakim opowiada Giddens. Pojawiający się w nich brak chronologii wywołany dominacją mechanizmów pamięci (indywidualnej, ale i zbiorowej) sprawia, że przeszłość staje się elementem teraźniejszości, jest nieustannie uobecniana i okazuje się najważniejszą płaszczyzną odniesienia dla ,ja" in statu nascendi. Owo stawanie się ,ja", tworzenie płynnej, rozwijającej się w czasie narracyjnej tożsamości uwidacznia się najsilniej w Pałacu.

Monolog Jakuba jest ciągiem historycznych epifanii, które stają się udziałem owczarza wędrującego po labiryncie pańskiej siedziby. Opisując to szczególne doświadczenie przeszłości, Myśliwski sięga po formę monologu wewnętrznego ${ }^{2}$ - czyli po tę odmianę narracji, która pozwala na najbardziej bezpośrednią ,relację z doznania”, na pozbawione dystansu narracyjnego „sprawozdanie” z doznań bohatera-narratora. Wydawałoby się, że jest to forma opowiadania najbardziej odpowiednia dla reprezentacji zmysłowego, spontanicznego doświadczenia. Tymczasem Pałac okazuje się tym utworem, który - w porównaniu z innymi powieściami, ale i dramatami Myśliwskiego - mówi o historii najmniej. Zaważyła na tym właśnie forma narracji: eksponująca medium, nie zaś samo doświadczenie. Wszystkie kroki Jakuba są stawaniem się, są drogą ku rozumieniu samego siebie, własnego losu i jego determinant. Kierunek poszukiwań i natura Jakubowej prze-

${ }^{2}$ Dokładniej rzecz ujmując, po jego bardziej uporządkowaną, uładzoną formę, czyli soliloqium. 
miany są uwarunkowane poczuciem przynależności do chłopskiej zbiorowości i równocześnie potrzebą jej przekroczenia. Ta ostatnia właściwość - świadomość pochodzenia z ,gromady” - połączona z głębokim odczuciem własnej wyjątkowości jest udziałem wszystkich bohaterów powieści Myśliwskiego - wszyscy oni definiowani są (także przez samych siebie) w kategoriach przynależności do ziemi, rodziny (zwłaszcza ojca), przeznaczenia i wszyscy pokonują podobną drogę: wyzwalają się z poczucia owej przynależności, by w autobiograficznej narracji odnaleźć (ponowić) związek z przeszłością. Dopiero odnalezienie sensu w przeszłości, przywrócenie, a właściwie: nadanie jej wartości (nierzadko graniczące z mityzacją czy sakralizacją) pozwala każdemu z nich na usensownienie własnego życia w procesie opowieści. Aksjologia minionego okazuje się nie tyle punktem wyjścia, co miejscem dojścia, pozwalającym na scalenie rozproszonych, nierzadko absurdalnych w swym kształcie losów.

\section{Bibliografia}

Auerbach E., 1968, Mimesis. Rzeczywistość przedstawiona w literaturze Zachodu, przeł. Z. Żabicki, Warszawa.

Balbus S., 2007, „Zagłada gatunków”, w: Polska genologia literacka, red. D. Ostaszewska, R. Cudak, Warszawa, s. 156-171.

Balcerzan E., 2007, Sytuacja gatunków, w: Polska genologia literacka, red. D. Ostaszewska, R. Cudak, Warszawa, s. 115-136.

Burzyńska A., 2013, Antyteoria literatury, Kraków.

Giddens A., 2010, Nowoczesność i tożsamość. „Ja” i spoleczeństwo w epoce późnej nowoczesności, przeł. A. Szulżycka, Warszawa.

Godlewski G., 2008, Stowo - pismo - sztuka stowa. Perspektywy antropologiczne, Warszawa.

Markowski M.P., 2007, Polska literatura nowoczesna. Leśmian, Schulz, Witkacy, Kraków. Mencwel A., 2006, Wyobraźnia antropologiczna. Próby i studia, Warszawa.

Myśliwski W., 2006, Traktat o tuskaniu fasoli, Kraków.

Myśliwski W., 2007, „Granice mojego języka oznaczaja granice mojego świata...”, w: O twórczości Wiestawa Myśliwskiego: w siedemdziesiątą rocznicę urodzin pisarza, t. 2, red. J. Pacławski, Kielce, s. 209-224.

Nycz R., 2000, Slowo wstępne, w: Dekonstrukcja w badaniach literackich, red. R. Nycz, Gdańsk.

Nycz R., 2001, Literatura jako trop rzeczywistości. Poetyka epifanii w nowoczesnej literaturze polskiej, Kraków.

Nycz R., 2006, Antropologia literatury - kulturowa teoria literatury - poetyka doświadczenia, w: Kulturowa teoria literatury, red. M.P. Markowski, R. Nycz, Kraków, s. 3449.

Ong W., 1992, Oralność i piśmienność. Słowo poddane technologii, przeł. J. Japola, Lublin.

Rosner K., 2003, Narracja, tożsamość i czas, Kraków.

Sławiński J., 2001, Co nam zostało ze strukturalizmu?, „Teksty Drugie”, z. 5, s. 15-17.

Steiner G., 1994, Zerwany kontrakt, przeł. O. Kubińska, Warszawa. 